\title{
Assessment of Heavy Metals Concentration in Soil and Plants from Baia Mare Area, NW Romania
}

\author{
Alina DONICI ${ }^{1}$, Claudiu Ioan BUNEA ${ }^{2}$, Anamaria CĂLUGĂR², Eugenia HARSAN ${ }^{3}$, Ionut RACZ ${ }^{4}$, Florin \\ Dumitru BORA ${ }^{*}$ \\ ${ }^{1}$ Department of Physico-Chemistry and Biochemistry, Research Station for Viticulture and Enology \\ Târgu Bujoru, Romania \\ ${ }^{2}$ Department of Horticulture and Landscape, University of Agricultural Sciences and Veterinary \\ Medicine, Cluj-Napoca, Romania \\ ${ }^{3}$ Department of Biochemistry University of Agricultural Sciences and Veterinary Medicine, \\ -Horticultural Research Station, Cluj-Napoca, Romania \\ ${ }^{4}$ Wheat Breeding Department, Agricultural Research and Development Station Turda, Cluj-Napoca, \\ Romania. \\ * corresponding author: boraflorindumitru@gmail.com
}

Bulletin UASVM Horticulture 75(2) / 2018

Print ISSN 1843-5262, Electronic ISSN 1843-536X

DOI:10.15835/buasvmcn-hort: 2018.0016

\begin{abstract}
The results showed diverse patterns of $\mathrm{Pb}, \mathrm{Cd}, \mathrm{Zn}, \mathrm{Co}, \mathrm{Cu}, \mathrm{Ni}, \mathrm{Mn}, \mathrm{Cr}$ and $\mathrm{Sn}$, in case of $\mathrm{Pb}$ in all areas exceeded the M.L.A (average $32.59 \mathrm{mg} / \mathrm{kg}$ while M.L.A. = $20 \mathrm{mg} / \mathrm{kg}$ ), other elements shows high concentration that exceed the M.L.A. for Ferneziu and Săsar area. In the case of plant material also records exceedances of the M.L.A for Ferneziu and Săsar area, but in the Dura area there were no overtaking of M.L.A.
\end{abstract}

Keywords: contaminated soil, soil pollution, heavy metals

\section{Introduction}

The town of Baia Mare used to be an important nonferrous metallurgical centre where heavy metals like $\mathrm{Pb}$ and $\mathrm{Cd}$ have been extracted and processed from centuries. Due to the aerial emissions form a metallurgical plant "Romplumb" that has been processing lead, located in the Ferneziu district, as well as from "Cuprom" plant that has been processing copper, located in the eastern part of the city, the soil in Baia Mare area is highly polluted with heavy metals: $\mathrm{Pb}, \mathrm{Cd}, \mathrm{Cu}, \mathrm{Zn}$, (Mihaly et al., 2013).

The main soil pollution sources are: mine entraces (mine openings), one processing factories, metallurgical factories $\mathrm{(a} \mathrm{Pb}$ and $\mathrm{Cu}$ smelter), and tailing ponds. The $\mathrm{Pb}$ smelter was closed in January 2012, after more than 150 years of production, and $\mathrm{Cu}$ smelter has been closed in
2018 afther more than 80 years of production. Currently the mining and metallurgical industry has reduced the activity by closing or diminishing the production capacity, however Baia Mare is facing the historical contamination of soil with heavy metals (Levei et al., 2009).

The present study aimed to assess the actual state of soil pollution taking into account the sources of soil pollution and the most exposed areas Ferneziu and Săsar district. The Ferneziu area has been impacted by the presence of the Pb smelter that is located in close poximity to the residential zones. The Săsar district is located along the Săsar River and is exposed to the dominant East to West wind. The paper aims to investigate the contents of heavy metals in soils and plants in Baia Mare area $\left(47^{\circ} 39^{\prime} \mathrm{N}, 23^{\circ} 34^{\prime} \mathrm{E}\right)$. 


\section{Materials and methods}

The sampling of soil and plant material was carried out during the vegetation period in May 2017. The study includes the sampling of the soil at the depth of 0-30 cm from Ferneziu, Săsar and Dura areas. In the same time, there has been collected plants growing in the same same location from where the soil samples had been drawn. They were collected Bentgrass (Agrostis sp.), Clover (Trifolium repens) and Nettle (Urtica dioica) from spontaneous flora.

The soil samples were dried, homogenized and then passed through a 20-mesh sieve to obtain very fine particles. The method for microwave digestion using a Milestone START D Microwave Digestion System, was optimized in a previous work (Bora et al., 2018): $0.25 \mathrm{~g}$ soil, $9 \mathrm{~mL}$ of $65 \% \mathrm{HNO}_{3}, 3 \mathrm{~mL}$ concentrate $\mathrm{HF}$ and $2 \mathrm{~mL}$ of concentrated $\mathrm{HCl}$ were placed in a clean Teflon digestion vessel. A total of 144 soils and 162 material samples were analysed, samples originated from Ferneziu, Săsar and Dura areas. The plant material samples (100 g per sample, hand-picked) were thoroughly washed with tap water followed by ultra-pure water using (Milli-Q Integral ultrapure waterType 1), after washing was oven dried at $80{ }^{\circ} \mathrm{C}$ to constant weight using a (FD 53 Binder). The method for microwave digestion using a Milestone START D Microwave Digestion System using plant material was optimized in a previous work (Bora et al., 2015): $1 \mathrm{~g}$ sample of plant material, $7 \mathrm{~mL}$ of $65 \% \mathrm{HNO}_{3}$ and $2 \mathrm{~mL}$ of $30 \% \mathrm{H}_{2} \mathrm{O}_{2}$ were placed in a clean Teflon digestion vessel.

The analysis was made using multielement analysis and ICP-MS (iCAP Q Thermo Scientific) technique, after an appropriate dilution, using external standard calibration method. The determination methodsforelements concentration from soils was optimized in a previous work (Bora et al., 2018).

\section{Results and discussions}

The element concentration in investigated soils varied among samples, but it is noticeable that examined elemental may considerably surpassed the M.A.L (Maximum Admissible Limit), this is particularly obvious in the case of $\mathrm{Pb}, \mathrm{Cd}, \mathrm{Zn}, \mathrm{Cu}, \mathrm{Ni}$ and $\mathrm{Cr}$. The highest concentrations were obtained in the Ferneziu and Săsar area for all metals, at the opposite pole there was the Dura area, which recorded the lowest heavy metals concentration.
In the case of Dura area it can be seen that the concentration of $\mathrm{Pb}$ and $\mathrm{Cd}$ also exceeds the M.A.L. $[32.59 \pm 1.47 \mathrm{mg} / \mathrm{kg}$ average value (M.L.A. $=20$ $\mathrm{mg} / \mathrm{kg} \mathrm{Pb}$ )], with regard to $\mathrm{Cd}$ concentration, this limits was exceeds only in the surface from $0-5 \mathrm{~cm}$ $(1.16 \pm 0.12 \mathrm{mg} / \mathrm{kg})$ and $5-10 \mathrm{~cm}(1.07 \pm 0.12 \mathrm{mg} /$ kg) (Tab. 1).

The highest concentration of metals from soil, was obtained by $\mathrm{Mn}(593.33 \pm 5.13 \mathrm{mg} / \mathrm{kg}$ average value) $>\mathrm{Cu}(408.41 \pm 1.83 \mathrm{mg} / \mathrm{kg}$ average value) $>\mathrm{Pb}(104.42 \pm 4.37 \mathrm{mg} / \mathrm{kg}$ average value $)>\mathrm{Zn}$ $(57.46 \pm 2.58 \mathrm{mg} / \mathrm{kg}$ average value $)>\operatorname{Cr}(29.39 \pm 0.53$ $\mathrm{mg} / \mathrm{kg}$ average value) $>$ Co $(11.60 \pm 0.18 \mathrm{mg} / \mathrm{kg}$ average value) $>\mathrm{Cd}(10.43 \pm 0.66 \mathrm{mg} / \mathrm{kg}$ average value) $>\mathrm{Ni}(9.82 \pm 0.65 \mathrm{mg} / \mathrm{kg}$ average value $)>$ Sn $(4.72 \pm 0.23 \mathrm{mg} / \mathrm{kg}$ average value). The highest concentrations of heavy metals can be assumed that are coming from antropogenic ativities $(\mathrm{Cd}$, $\mathrm{Pb}, \mathrm{Cu}$ and $\mathrm{Zn}$ mining and non-ferrous metallurgy) and $\mathrm{Co}, \mathrm{Cr}, \mathrm{Mn}$ and also $\mathrm{Ni}$ are rather related to their natural occurrence in soil. The results obtained are comparable to those obtained by Mihaly et al. (2013) $115.00-19.195$ [Pb (mg/kg)], 0.15-113.00 [Cd (mg/kg)], 100.000-3791.00 [Zn (mg/kg)], 0.20-23.50 [Co (mg/kg)], 6.50-1730.00 [Cu (mg/ $\mathrm{kg})], 0.20-29.30$ [Ni (mg/kg)], 4.25-2124.00 [Mn $(\mathrm{mg} / \mathrm{kg})], 0.20-50.50$ [Cr (mg/kg)] and 1.30-21.40 [Sn (mg/kg)].

Concerning the concentration of metals in plants, it can be seen that $\mathrm{Pb}, \mathrm{Cd}, \mathrm{Zn}$ and $\mathrm{Cu}$ they exceeded the M.A.L. for Ferneziu and Săsar area. Bentgrass (Agrostis sp.) has recorded high concentration at $\mathrm{Pb}, \mathrm{Zn}, \mathrm{Ni}$ (Ferneziu), Clover (Trifolium repens) has recorded high concentration at Cd, Co and Sn (Ferneziu) and Nettle (Urtica dioica) has recorded high concentration at $\mathrm{Zn}$, Co and Sn (Săsar) (Tab. 2). In case of Dura area, all the elemental studied were under the maximum limit admitted. The highest concentration of metals from plants, was obtained by Mn $(116.68 \pm 2.89$ $\mathrm{mg} / \mathrm{kg}$ average value $)>\mathrm{Zn}(84.45 \pm 0.31 \mathrm{mg} / \mathrm{kg}$ average value $)>\mathrm{Cu}(32.74 \pm 1.32 \mathrm{mg} / \mathrm{kg}$ average value $)>\mathrm{Pb}(23.83 \pm 1.08 \mathrm{mg} / \mathrm{kg}$ average value $)>\mathrm{Cd}$ $(2.25 \pm 0.14 \mathrm{mg} / \mathrm{kg}$ average value $)>\mathrm{Cr}(2.22 \pm 0.11$ $\mathrm{mg} / \mathrm{kg}$ average value) $>\mathrm{Ni}(1.71 \pm 0.13 \mathrm{mg} / \mathrm{kg}$ average value $)>$ Co $(0.65 \pm 0.04 \mathrm{mg} / \mathrm{kg}$ average value) $>$ Sn $(0.25 \pm 0.03 \mathrm{mg} / \mathrm{kg}$ average value $)$. The results obtained are comparable to those obtained by Mihaly et al. (2013) 1.04-255.00 [Pb (mg/kg)], $0.02-4.81$ [Cd (mg/kg)], 30.10-199.00 [Zn (mg/ $\mathrm{kg})$ ], 0.03-0.46 [Co (mg/kg)], 0.35-33.60 [Cu (mg/ 


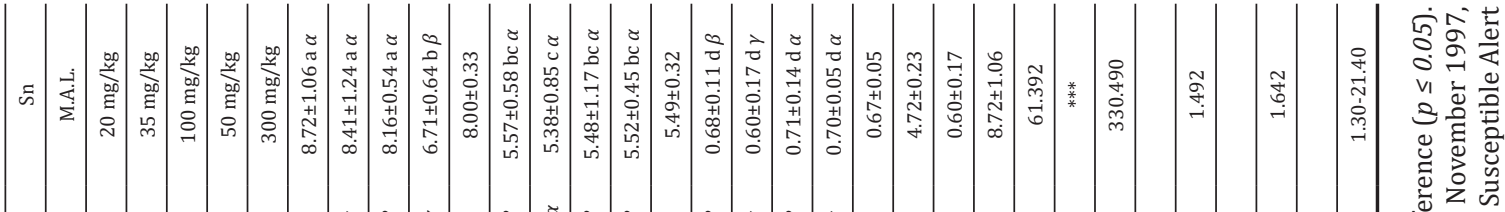

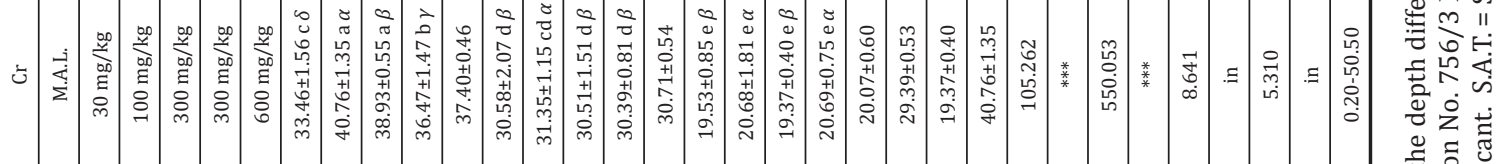

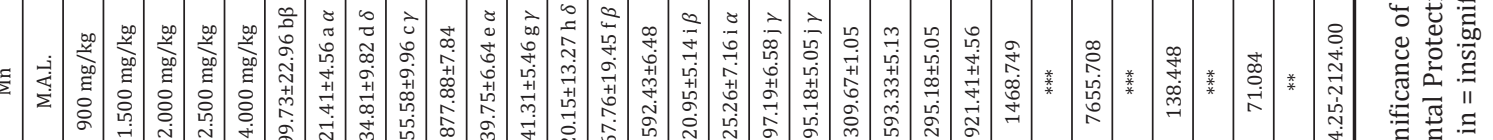

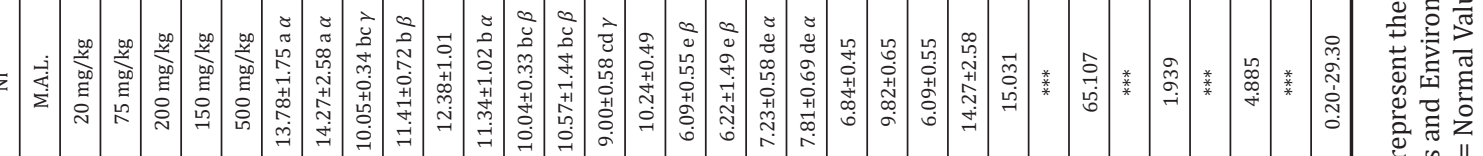

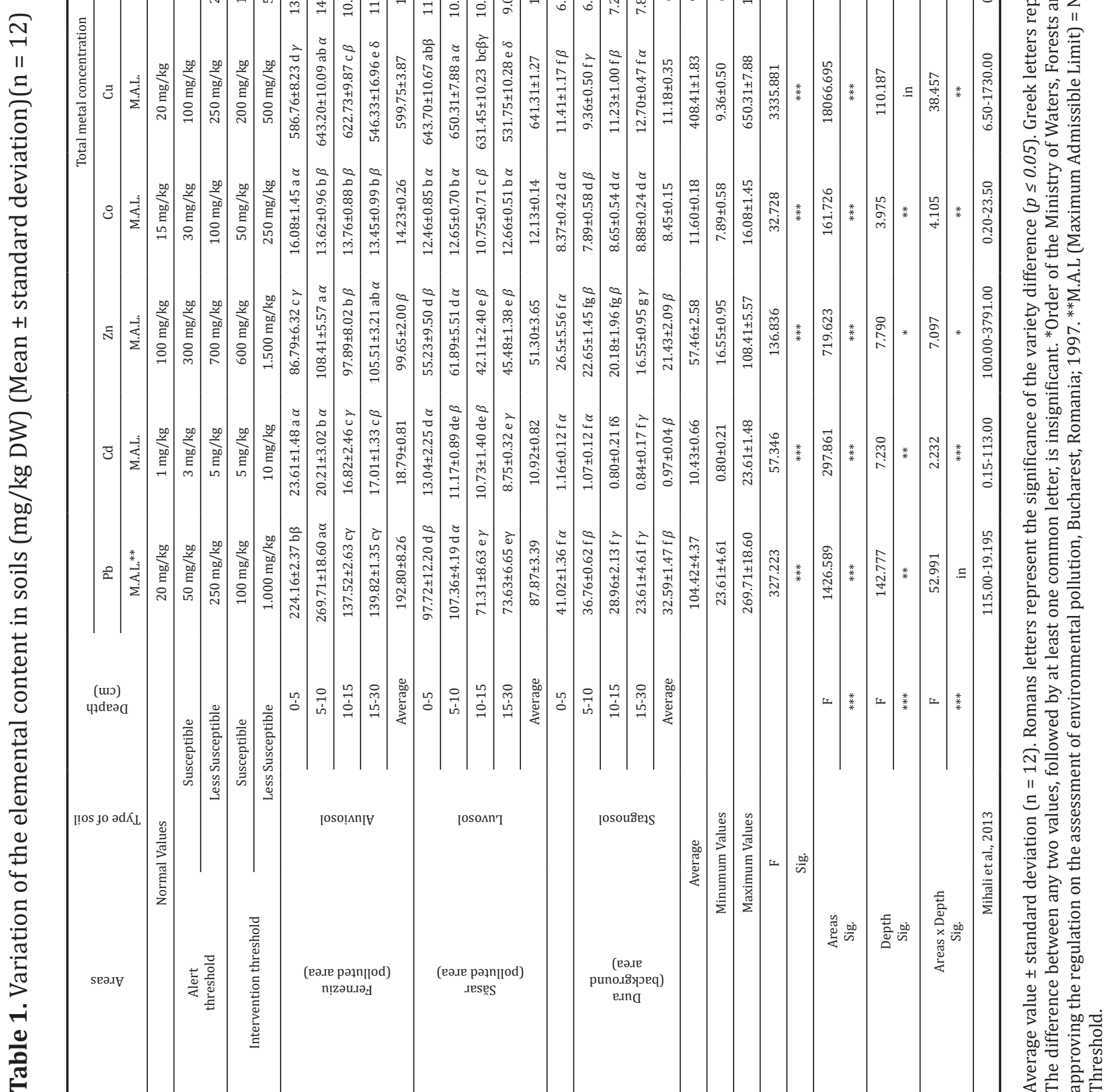




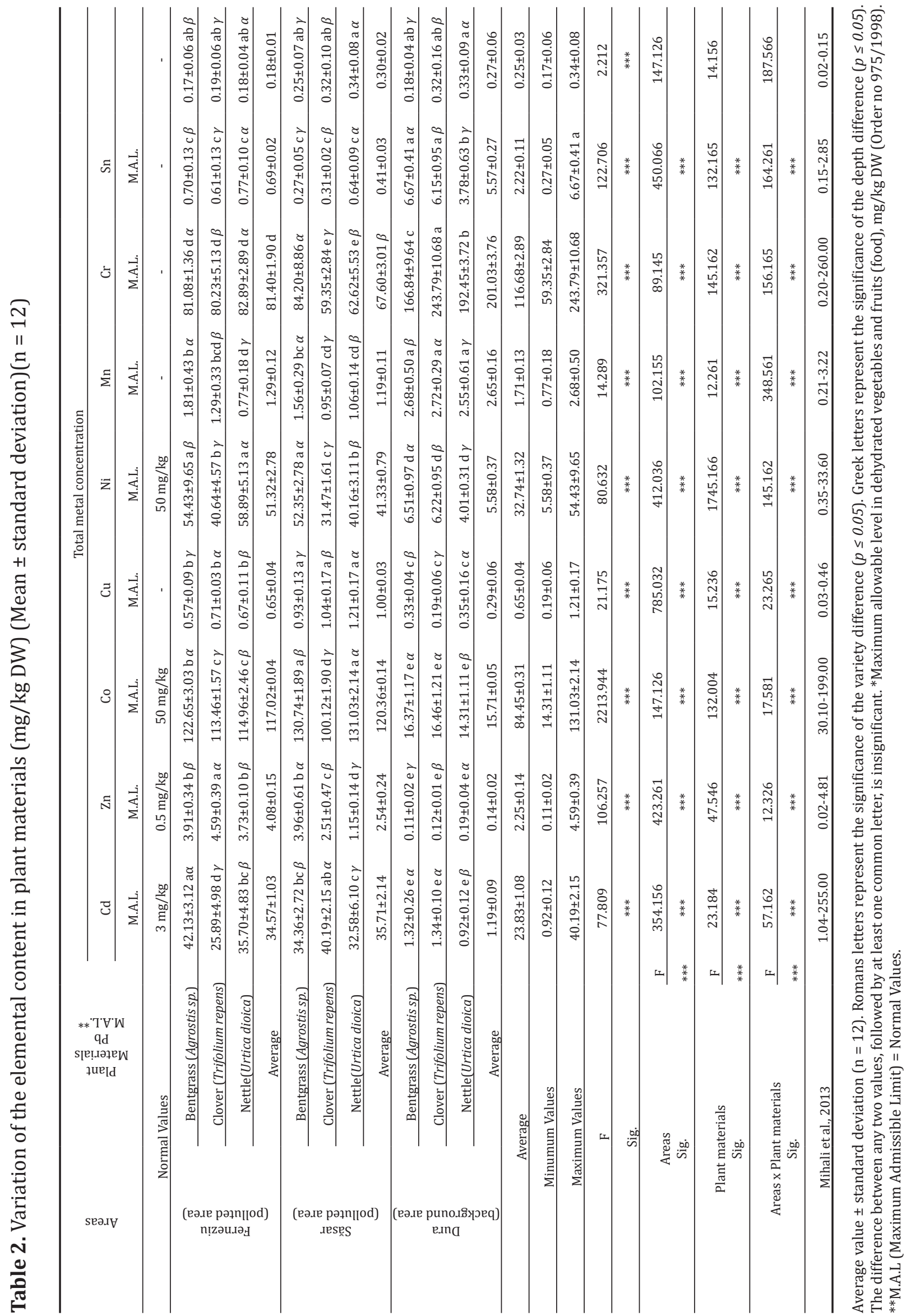




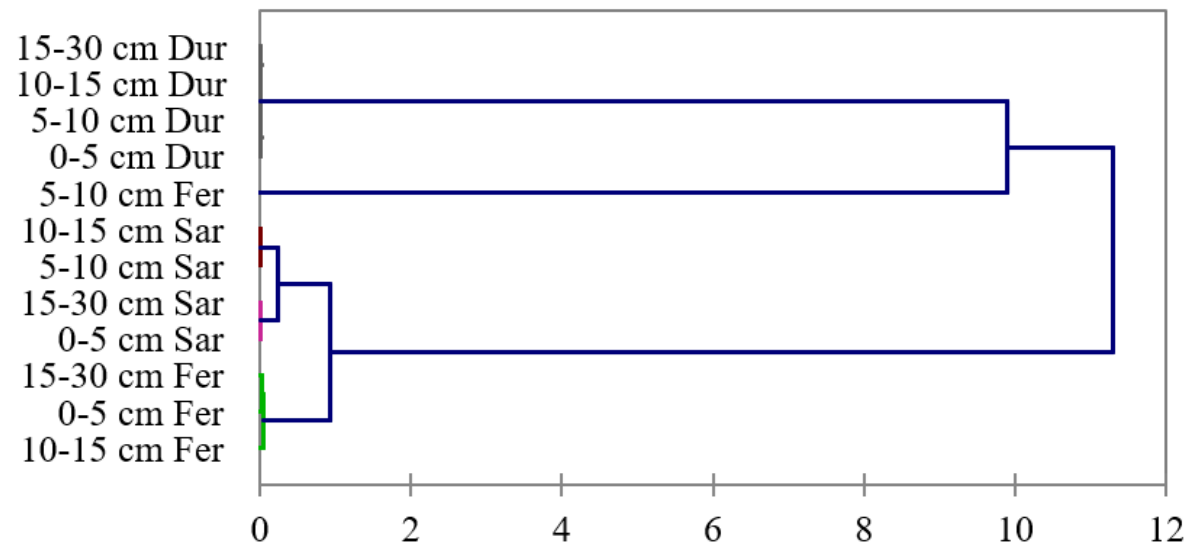

Figure 1. Hierarchical dendrogram for pollut areas based on heavy metals content in soils

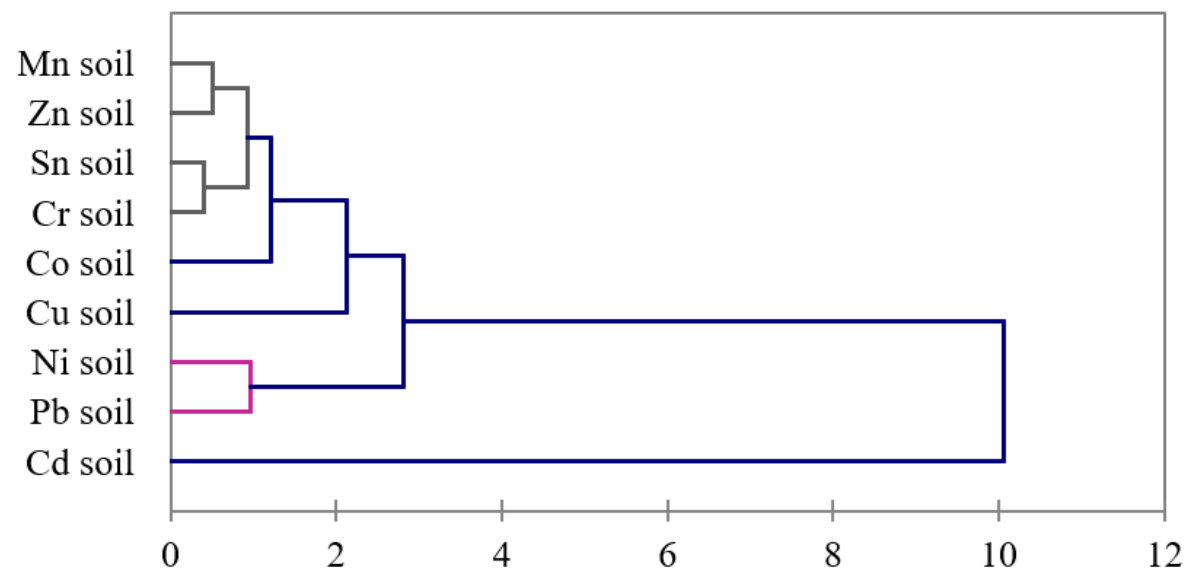

Figure 2. Hierarchical dendrogram for heavy metals in soils

$\mathrm{kg})], 0.21-3.22[\mathrm{Ni}(\mathrm{mg} / \mathrm{kg})], 0.20-260.00[\mathrm{Mn}$ $(\mathrm{mg} / \mathrm{kg})], 0.15-2.85[\mathrm{Cr}(\mathrm{mg} / \mathrm{kg})]$ and $0.02-0.15$ [Sn (mg/kg)].

The hierarchical dendrogram for polluted areas based on heavy metals content in sol material (Fig. 1) shown the contaminated locations are group in two primary clusters. The first cluster is formed of the sites which are located in Dura area, while the second one is formed of the sites of Ferneziu and Săsar. In terms of measure interval, the difference between these two-primary cluster is significant, which suggests that the level of soil pollution is significant higher in Ferneziu and Săsar area. Both primary cluster are further divide into several new subclusters. The position of an isolated subcluster which belongs to the Dura area, suggests that this area does not show severe pollution with heavy metals.

The dendrogram from heavy metals in soil (Fig. 2) shows the grouping of the elements in to main cluster: one isolated for $\mathrm{Cd}$ and other for the rest of elements, as numerous different subclusters. It terms of measure interval the difference between these two primary clusters is significant, which confirms that the source of $\mathrm{Cd}$ content in soils is simple, geology, whereas the contents of other metals in soils under the influence of atmospheric pollution. The largest influence of this pollution is reflected on the content of $\mathrm{Cu}, \mathrm{Pb}$ and $\mathrm{Zn}$.

\section{Conclusions}

In soils, the results showed diverse patterns of $\mathrm{Pb}, \mathrm{Cd}, \mathrm{Zn}, \mathrm{Co}, \mathrm{Cu}, \mathrm{Ni}, \mathrm{Mn}, \mathrm{Cr}$ and $\mathrm{Sn}$, in case of $\mathrm{Pb}$ in all areas exceeded the M.L.A (average 32.59 $\mathrm{mg} / \mathrm{kg}$ while M.L.A. $=20 \mathrm{mg} / \mathrm{kg}$ ), other elements shows high concentration that exceed the M.L.A. for Ferneziu and Săsar area. In the case of plant material also records exceedances of the M.L.A for Ferneziu and Săsar area, but in the Dura area there were no overtaking of M.L.A. The hierarchical dendrogram for polluted areas shown that the 
Ferneziu and Săsar shows the highest trace of heavy metals pollution while the Dura area does not show severe pollution with heavy metals. The dendrogram from heavy metals in soil shows the Cd content in soils is simple, geology, and the largest influence of this pollution is reflected on the content of $\mathrm{Cu}, \mathrm{Pb}$ and $\mathrm{Zn}$.

\section{References}

1. Bora FD, Bunea CI, Nastasia P (2015). Vertical distribution and analysis of micro-, macroelements and heavy metals in the system soil-grapevine-wine from North-West Romania. Chemistry Central Journal, 9(19):1-13.

2. Bora FD, Donici A, Rusu T, Bunea A, Popescu D, Bunea CI (2018). Elemental profile and ${ }^{207} \mathrm{~Pb} /{ }^{206} \mathrm{~Pb},{ }^{208} \mathrm{~Pb} /{ }^{206} \mathrm{~Pb}$,
${ }^{204} \mathrm{~Pb} /{ }^{206} \mathrm{~Pb},{ }^{87} \mathrm{Sr} /{ }^{87} \mathrm{Sr}$ isotope ratio as fingerprints for geographical traceability of Romanian wines. Notulae Botanicae Horti Agrobotanici Cluj-Napoca, 46(1): 223239.

3. Mihali C, Oprea G, Michnea A, Jelea SG, Jelea M, Man C, Șenilă M, Grigor L (2013). Assessement of heavy metlas content and pollution level in sol and plants in Baia Mare area, NW Romania. Carpathian Journal of Earth and Environmental ciences, 8(2): 143-152.

4. Levei EA, Frențiu T, Ponta M, Șenilă M., Miclean M, Romani C, Cordoss E (2009). Characterization of soil quality and mobility of $\mathrm{Cd}, \mathrm{Cu}, \mathrm{Pb}$ and $\mathrm{Zn}$ in the Baia Mare area Northwest Romania following the historical pollution. International Journal of Environmental Analytical Chemistry 89: 635-649. 